\title{
Reovirus-Specific Messenger Ribonucleoprotein Particles from Hela Cells
}

\author{
Jürgen Kreft \\ Biologisches Institut der Universität Stuttgart \\ Z. Naturforsch. 35 c, 1046- 1051 (1980); \\ Hela Cells, Reovirus, Messenger Ribonucleoprotein Particles, mRNP-Proteins, \\ Electron Microscopy \\ When reovirus-infected Hela cells are incubated at $43^{\circ} \mathrm{C}$ virus-specific messenger RNA is \\ released from the polysomes. It accumulates free in the cytoplasm as messenger ribonucleopro- \\ tein particles (mRNPs). These particles have a sedimentation rate of about $50 \mathrm{~S}$ and a buoyant \\ density in $\mathrm{CsCl}$ of $1.42 \mathrm{~g} / \mathrm{cm}^{3}$. Reovirus mRNPs contain, besides all three size classes of reovirus \\ messenger RNA, the same spectrum of proteins found in the polysomal mRNPs from uninfected \\ cells, plus two additional proteins with molecular masses of $70000 \mathrm{~d}$ and $110000 \mathrm{~d}$, respectively. \\ Electron microscopic examination of the reovirus mRNP fraction reveals specific Y-shaped \\ structures with a total mean length of $0.5 \mu \mathrm{m}$.
}

\section{Introduction}

The genome of the reoviruses consists of doublestranded RNA which is enclosed within the virus capsid as ten segments falling into three size classes, named $\mathrm{L}, \mathrm{M}$ and $\mathrm{S}$ [1, 2]. In infected host cells each of these segments is transcribed into single-stranded messenger RNA molecules [3] by a virus-associated transcriptase [4]. These viral mRNAs are translated by the host cell polysomes and can be released from these either in vitro by treatment with ethylenediamine tetraacetic acid (EDTA) [5, 6] or in vivo by blocking the initiation of protein synthesis [7]. In both cases the viral mRNA is found in the form of messenger ribonucleoprotein particles (reo-mRNPs), the bulk of which sediments around $50 \mathrm{~S}$ in sucrose gradients [5-7]. These particles contain all three size classes $(1, \mathrm{~m}, \mathrm{~s})$ of reovirus $\mathrm{mRNA}$, their protein composition has repeatedly been analysed, but with divergent results. In one report viral capsomere proteins have been found as major constituents [5], others found no virus-coded proteins at all [7], in a third report the presence of the non-capsid protein $\sigma 2 \mathrm{~A}$ has been demonstrated [6].

\section{Materials and Methods}

Hela cells (S3) were grown in suspension culture with Eagles minimum essential medium supple-

Abbreviations: EDTA, ethylenediamine tetraacetic acid; mRNA, messenger ribonucleic acid; mRNP, messenger ribonucleoprotein particle; SDS, sodium dodecyl sulfate; Tris, tris (hydroxymethyl) aminomethane.

Reprint requests to Dr. Jürgen Kreft, Institut für Genetik und Mikrobiologie, Röntgenring 11, D-8700 Würzburg. mented with $5 \%$ calf serum to a cell density of $5 \times 10^{5} \mathrm{cells} / \mathrm{ml}$. Reovirus type 3 was originally isolated and classified by Dr. Schwöbel (Tübingen). Virus propagation, titer assays by plaque formation on mouse L cells or by hemagglutination and virus purification by density gradient centrifugation in cesium chloride have previously been described [8-10].

For the in vivo dissociation of polysomes the cells were incubated for $20 \mathrm{~min}$ at $43^{\circ} \mathrm{C}$ [17], then poured on crushed frozen saline, washed once and resuspended in cold buffer $\mathrm{A}(10 \mathrm{~mm}$ Tris/ $\mathrm{HCl} \mathrm{pH}$ $7.4,3 \mathrm{~mm} \mathrm{MgCl}_{2}, 7 \mathrm{~mm}$ mercaptoethanol, $10 \mathrm{~mm}$ $\mathrm{KCl}$ ). After $10 \mathrm{~min}$ swelling the cells were gently homogenized in a Dounce homogenizer, Triton $\mathrm{X}-100$ was added to a final concentration of $1 \%$ and the nuclei were sedimented by centrifugation ( 700 $\times g, 4 \mathrm{~min}, 4^{\circ} \mathrm{C}$ ). The supernatant was centrifuged $\left(30000 \times g, 20 \mathrm{~min}, 4^{\circ} \mathrm{C}\right)$ to remove membranes and mitochondria. This postmitochondrial supernatant was centrifuged through sucrose gradients as indicated in the legends to the figures.

The proteins from messenger ribonucleoprotein particles obtained by pelleting the appropriate fractions from sucrose gradients were solubilized by incubation of the mixture of these particles and contaminating ribosomes with pancreatic ribonuclease $(2 \mu \mathrm{g} / \mathrm{ml})$ for $20 \mathrm{~min}$ at $20^{\circ} \mathrm{C}$ in buffer B (as buffer $\mathrm{A}$, but with $500 \mathrm{mM} \mathrm{KCl}$ ). The reaction mixture was layered on a cushion of $15 \%$ sucrose in buffer $\mathrm{A}$ and centrifuged in a truncated tube $(2.2 \mathrm{~cm}$, rotor SW $50,45000 \mathrm{rpm}, 2.25 \mathrm{~h}, 4{ }^{\circ} \mathrm{C}$ ). The upper third $(0.6 \mathrm{ml})$ of the tube content was used for the protein analysis [11]. 
For electron microscopic examination the messenger ribonucleoprotein particles were suspended in buffer A, mixed with one volume of a cytochrome $\mathrm{C}$ solution $(60 \mu \mathrm{g} / \mathrm{ml}$ in $0.3 \mathrm{M}$ ammoniumacetate $\mathrm{pH} 7.1$ ), a drop of $50 \mu \mathrm{l}$ was pipetted on a paraffin sheet. After 5 min a parlodion/carbon coated grid (400 mesh) was brought in contact with the surface of the drop, then stained for $30 \mathrm{sec}$ with uranylacetate $\left(2 \times 10^{-5} \mathrm{M}\right.$ in ethanol), washed once, dried and examined without any further treatment in a Zeiss EM 10 electron microscope at $60 \mathrm{kV}$.

The proteins from mRNPs were lyophilized, dissolved in sample buffer $(10 \mathrm{~mm}$ Tris/ $\mathrm{HCl} \mathrm{pH} 7.4$, $24 \mathrm{~mm}$ mercaptoethanol, 4\% SDS, 10\% glycerol), heated for $1 \mathrm{~min}$ at $90^{\circ} \mathrm{C}$ and separated on discontinuous acrylamide slab gels [15]. The stacking gel contained $5 \%$ acrylamide in $125 \mathrm{mM}$ Tris $/ \mathrm{HCl}$ pH 7.8, the separation gel $10 \%$ acrylamide in $360 \mathrm{~mm}$ Tris/ $\mathrm{HCl} \mathrm{pH} 8.8$, the electrode buffer $50 \mathrm{~mm}$ Tris/ $\mathrm{HCl} \mathrm{pH} 8.6,385 \mathrm{~mm}$ glycine; the gels and the electrode buffer contained $0.2 \%$ SDS, electrophoresis was carried out at $75 \mathrm{~mA}$. The gels were stained with coomassie blue and scanned at $580 \mathrm{~nm}$. The molecular masses of the proteins were calculated by comparison with marker proteins [16].

Further experimental details are given in the legends to the figures.

\section{Results and Discussion}

As found earlier in our laboratory arrest of protein synthesis and breakdown of polysomes can be induced in Hela cells by incubation at $43^{\circ} \mathrm{C}$ for $20 \mathrm{~min}$. After this treatment the bulk of cellular mRNA, rapidly labeled in the presence of $0.05 \mu \mathrm{g}$ / $\mathrm{ml}$ actinomycin $\mathrm{D}$, sediments in sucrose gradients near the monoribosomal peak and represents polysomal messenger ribonucleoprotein particles (psmRNPs) $[8,17]$ (Fig. 1 a). The dissociation is reversible by lowering the temperature again to $37^{\circ} \mathrm{C}$ and apparently does not lead to a damage of the ribosomes or the messenger ribonucleoprotein. At a concentration of $0.2 \mu \mathrm{g} / \mathrm{ml}$ actinomycin D the synthesis of cellular mRNA is almost completely blocked and the polysomes dissociate. Reovirus mRNA, however, continues to be synthesized at this concentration of actinomycin D and therefore can be selectively labeled [18]. The polysomes in reovirus-infected Hela cells also remain stable at this concentration of the drug, but can again be dissociated by incubation of the cells at $43^{\circ} \mathrm{C}$. Reovirus mRNA derived from the polysomes can be isolated from the postmitochondrial supernatant as a fraction sedimenting with $50 \mathrm{~S}$ (Fig. $1 \mathrm{~b}$ ). In non-infected cells treated in the same way no such peak at this position can be found. Since the largest species of reovirus mRNA sediments with $25 \mathrm{~S}$, the $50 \mathrm{~S}$ fraction most likely contains the viral mRNA in a complexed form, e.g. associated with protein and/or ribosomal subunits. To reveal the nature of these complexes they were fixed with $3 \%$ glutaraldehyde [19] and banded in performed $\mathrm{CsCl}$ density gradients. Fig. 2 shows that the fixed particles have a mean buoyant density in $\mathrm{CsCl}$ of $1.42 \mathrm{~g} / \mathrm{cm}^{3}$, from which a protein content of $70 \%$ can be estimated [20]. Such a density is characteristic for mRNPs, whereas complexes of mRNPs with the small ribosomal subunit have a density of $1.47 \mathrm{~g} / \mathrm{cm}^{3}$ [17]. It must be noted that unfixed particles did not show any change in their sedimentation rate when they were centrifuged through sucrose gradients with concentrations of $\mathrm{KCl}$ up to $250 \mathrm{~mm}$ (results not
Fig. 1. Effect of elevated incubation temperature. Hela cells were infected with $15 \mathrm{PFU} /$ cell of reovirus 3. After $14 \mathrm{~h}$ at $37^{\circ} \mathrm{C}$ actinomycin $\mathrm{D}$ was added to these cells and to uninfected cells $(0.2$ and $0.05 \mu \mathrm{g} / \mathrm{ml}$, respectively). At this time the synthesis of reovirus mRNA reaches a maximum. The cells were then labeled with $74 \mathrm{KBq} / \mathrm{ml}\left[{ }^{3} \mathrm{H}\right]$ uridine for two $h$. The postmitochondrial supernatant was centrifuged through $15-30 \%$ sucrose gradients in buffer $\mathrm{A}$ (rotor SW 27, $200000 \mathrm{rpm}, 17 \mathrm{~h}, 4^{\circ} \mathrm{C}$ ). Fractions of the gradients were analyzed for absorbance at $260 \mathrm{~nm}$ and for radioactivity precipitable with cold $5 \%$ trichloro acetic acid a) Uninfected cells; b) reovirus-infected cells.




shown). This is some evidence for the assumption that the $50 \mathrm{~S}$ particles represent genuine complexes rather than artificial ones.

\section{Analysis of the RNA and protein composition}

Separation of purified RNA from the $50 \mathrm{~S}$ fraction described above by gel electrophoresis shows that mainly RNA species with molecular masses of $0.4 \times 10^{6}, 0.7 \times 10^{6}$ and $1.3 \times 10^{6} \mathrm{~d}$ are present (Fig. 3 ). This corresponds well to the values given for the $14 \mathrm{~S}(\mathrm{~s}), 18 \mathrm{~S}(\mathrm{~m})$ and $25 \mathrm{~S}(\mathrm{l})$ species of reovirus mRNA [3]. The minor peaks migrating faster than the $0.4 \times 10^{6} \mathrm{~d}$ species must represent degradation products of reovirus mRNA since cellular RNA synthesis is almost completely blocked under the conditions which were used. This result clearly shows that the rapidly labeled $50 \mathrm{~S}$ fraction, only found in reovirus-infected cells, consists of reovirus-specific mRNPs (reo-mRNPs).

Sucrose gradient fractions containing reo-mRNPs or ps-mRNPs are inevitably contaminated by ribosomes and ribosomal subunits. Unfortunately, since reovirus mRNA lacks a poly(A)-sequence [21], reomRNPs cannot be separated from the ribosomes by affinity chromatography, e.g. on poly(U)-sepharose.

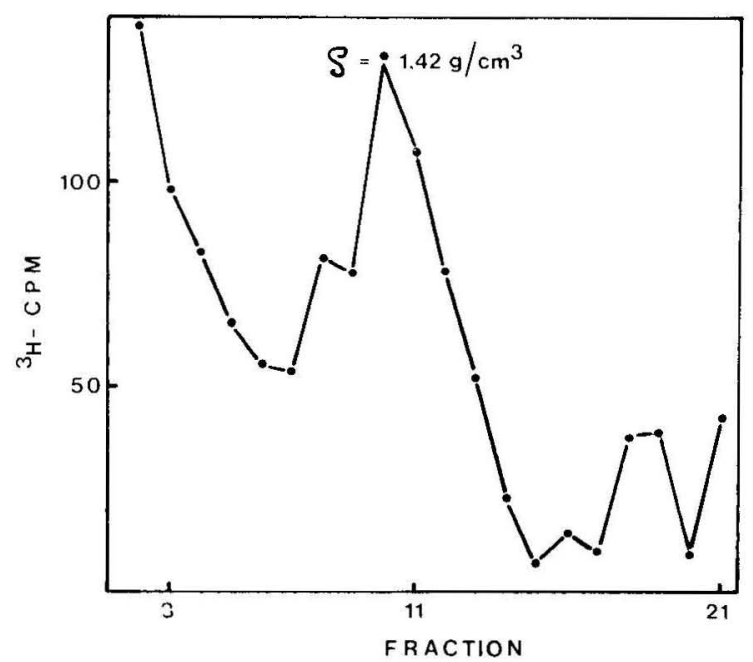

Fig. 2. Buoyant density of reo-mRNPs in $\mathrm{CsCl}$. The $50 \mathrm{~S}$ fraction from reovirus-infected Hela cells was prepared as described in Fig. 1 and pelleted in the rotor $50 \mathrm{Ti}$ (45000 $\mathrm{rpm}, 16 \mathrm{~h}, 4^{\circ} \mathrm{C}$ ). The particles were resuspended in buffer $\mathrm{A}$, fixed for $1 \mathrm{~min}$ at $4^{\circ} \mathrm{C}$ with neutralized glutaraldehyde at a final concentration of $3 \%$ [19] and layered on preformed $\mathrm{CsCl}$ density gradients in buffer A (density $1.25-1.55 \mathrm{~g} / \mathrm{cm}^{3}$ ). Centrifugation was in the rotor SW 56 at $35000 \mathrm{rpm}$ for $16 \mathrm{~h}$ at $4^{\circ} \mathrm{C}$.

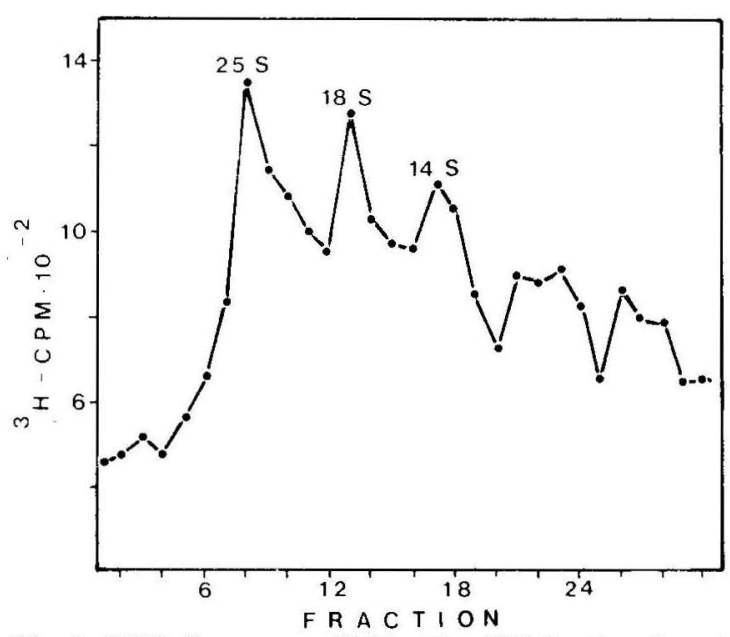

Fig. 3. RNA from reo-mRNPs. The $50 \mathrm{~S}$ fraction from infected Hela cells was prepared as described in Fig. 1, the RNA was extracted with chloroform/phenol 1:1 [12] and analyzed by electrophoresis on polyacrylamide/agarose composite gels $[13,14]$. The gels contained $2.2 \%$ acryl-

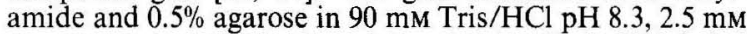
$\mathrm{Na}_{2}$-EDTA, $0.15 \mathrm{M}$ boric acid and $0.2 \%$ SDS. Unlabeled ribosomal RNA was used as a marker.

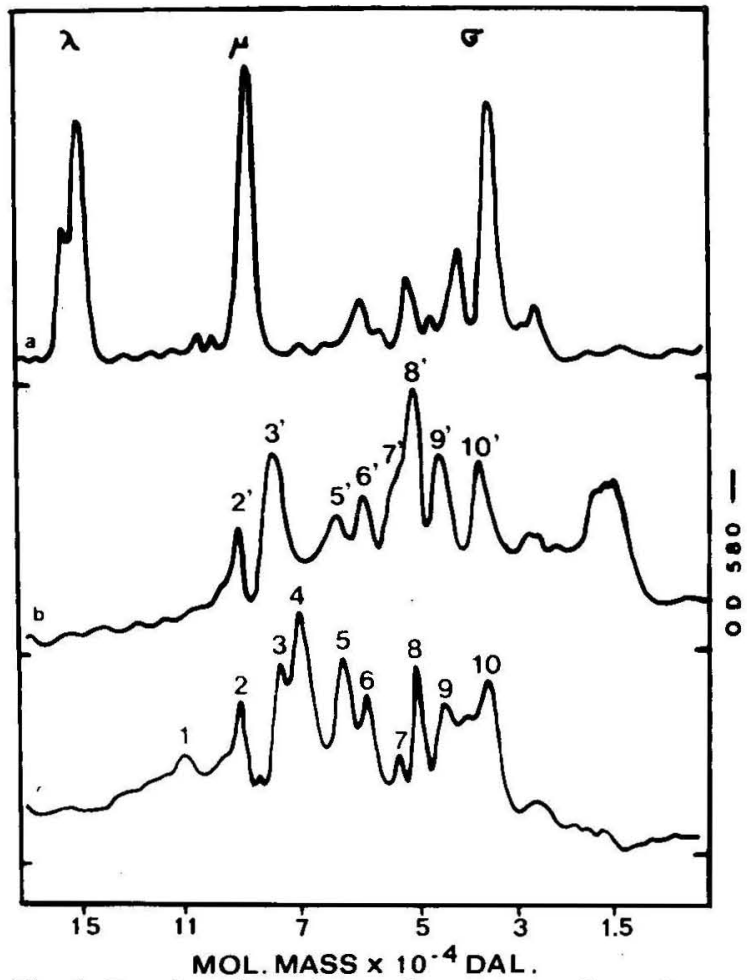

Fig. 4. Proteins of reovirus and messenger ribonucleoprotein particles. The analysis was performed on $10 \%$ polyacrylamide gels (see materials and methods), the stained gels were scanned at $580 \mathrm{~nm}$. a) Purified reovirus; b) psmRNPs from uninfected cells; c) reo-mRNPs from reovirus-infected cells. 

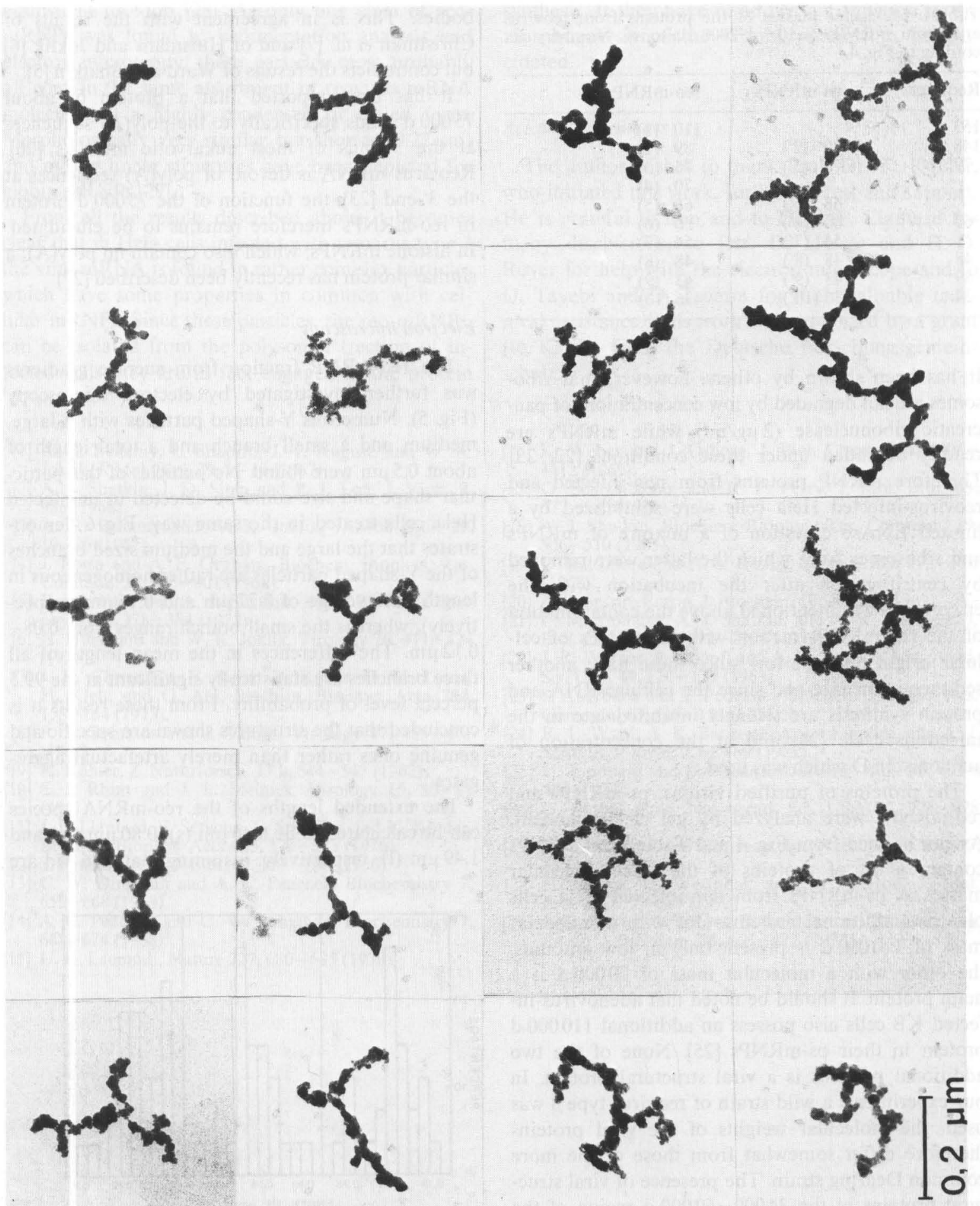

Fig. 5. Electron micrographs of reo-mRNPs from the $50 \mathrm{~S}$ fraction of reovirus-infected cells. Three of the micrographs at the right show two particles each. 
Table I. Molecular masses of the proteins from reovirus and from mRNPs $\left(\times 10^{-3} \pm 2000\right.$ daltons $)$. Numbers according to Fig. 4.

\begin{tabular}{lll}
\hline Reovirus & ps-mRNPs & reo-mRNPs \\
\hline 153 & & $110(1)$ \\
148 & $89\left(2^{\prime}\right)$ & $89(2)$ \\
79 & $76\left(3^{\prime}\right)$ & $76(3)$ \\
& $66\left(5^{\prime}\right)$ & $70(4)$ \\
60 & $60\left(6^{\prime}\right)$ & $66(5)$ \\
& $54\left(7^{\prime}\right)$ & $60(6)$ \\
48 & $48\left(8^{\prime}\right)$ & $54(7)$ \\
39 & $43\left(9^{\prime}\right)$ & $48(8)$ \\
34 & $36\left(10^{\prime}\right)$ & $36(10)$ \\
\hline
\end{tabular}

It has been shown by others, however, that ribosomes are not degraded by low concentrations of pancreatic ribonuclease $(2 \mu \mathrm{g} / \mathrm{ml})$ while mRNPs are readily degraded under these conditions [22, 23]. Therefore mRNP proteins from non-infected and reovirus-infected Hela cells were solubilized by a limited RNAse digestion of a mixture of mRNPs and ribosomes from which the latter were removed by centrifugation after the incubation with the enzyme. As was mentioned above the contamination of the reo-mRNP fraction with ps-mRNPs of cellular origin must be low since these have another sedimentation rate and since the cellular RNA and protein synthesis are strongly inhibited late in the infectious cycle [24] and at the concentration of actinomycin $\mathrm{D}$ which was used.

The proteins of purified virions, ps-mRNPs and reo-mRNPs were analyzed by gel electrophoresis. As can be seen from Fig. 4 and Table I reo-mRNPs contain a set of proteins of the same molecular masses as ps-mRNPs from non-infected Hela cells plus two additional proteins. One with a molecular mass of $110000 \mathrm{~d}$ is present only in low amounts, the other with a molecular mass of $70000 \mathrm{~d}$ is a main protein. It should be noted that adenovirus-infected KB cells also possess an additional $110000 \mathrm{~d}$ protein in their ps-mRNPs [25]. None of the two additional proteins is a viral structural protein. In our experiments a wild strain of reovirus type 3 was used, the molecular weights of the viral proteins therefore differ somewhat from those of the more common Dearing strain. The presence of viral structural proteins in the $34000-60000 \mathrm{~d}$ region of the gels cannot be excluded by the method but no such proteins could be detected in the reo-mRNP fraction by immunoprecipitation with specific anti- bodies. This is in agreement with the results of Christman et al. [7] and of Huismans and Joklik [6] but contradicts the results of Ward and Shatkin [5].

It has been reported that a protein of about $75000 \mathrm{~d}$ binds specifically to the poly(A) sequences at the 3'-ends of most eukaryotic mRNAs [26]. Reovirus mRNA is devoid of poly(A) sequences at the 3 '-end [23], the function of the $75000 \mathrm{~d}$ protein in reo-mRNPs therefore remains to be elucidated. In histone mRNPs, which also contain no poly(A), a similar protein has recently been described [27].

\section{Electron microscopy}

The reo-mRNP fraction from sucrose gradients was further investigated by electron microscopy (Fig. 5). Numerous Y-shaped particles with a large, medium and a small branch and a total length of about $0.5 \mu \mathrm{m}$ were found. No particles of this particular shape and size could be detected in uninfected Hela cells treated in the same way. Fig. 6 demonstrates that the large and the medium sized branches of the Y-shaped particles are rather homogeneous in length (an average of $0.22 \mu \mathrm{m}$ and $0.16 \mu \mathrm{m}$, respectively), whereas the small branch ranges from 0.08 $0.12 \mu \mathrm{m}$. The differences in the mean length of all three branches are statistically significant at the 99.5 percent level of probability. From these results it is concluded that the structures shown are specific and genuine ones rather than merely artefactual aggregates.

The extended lengths of the reo-mRNA species can be calculated to be $0.46 \mu \mathrm{m}(\mathrm{s}), 0.80 \mu \mathrm{m}(\mathrm{m})$ and $1.49 \mu \mathrm{m}(\mathrm{l})$, respectively, assuming that $0.86 \mathrm{Md}$ are

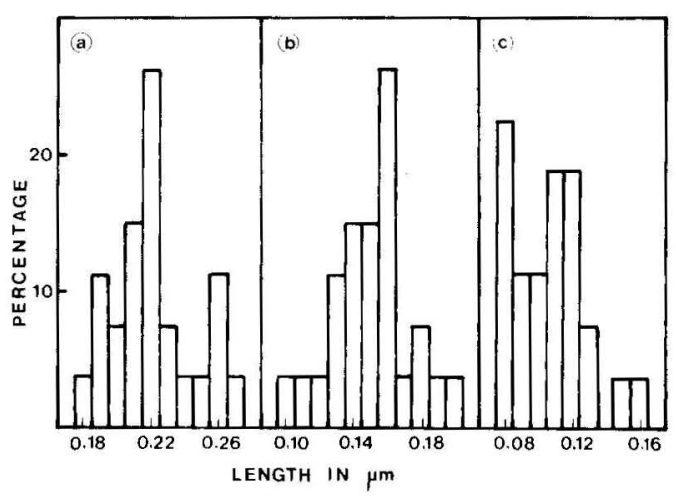

Fig. 6. Length distribution of the three branches of reomRNPs. The contour lengths were measured on large scale prints. a) Large branch; b) medium sized branch; c) small branch. 
equivalent to $1 \mu \mathrm{m}$ [28]. As only one class of reomRNPs was found by sedimentation analysis and electron microscopy, these particles most probably all contain the same assortment of reovirus mRNA molecules in a highly condensed or coiled form. Morphologically very similar but shorter $(0.22 \mu \mathrm{m})$ and mostly linear structures have been depicted for globin mRNPs [29].

From all the results described above it becomes clear that in Hela cells infected with reovirus type 3 the viral mRNA is found in rather complex particles which have some properties in common with cellular mRNPs. Since these particles, the reo-mRNPs, can be isolated from the polysomal fraction of infected cells they are in fact engaged in the protein

[1] A. R. Bellamy, L. Shapiro, J. T. August, and W. K. Joklik, J. Mol. Biol. 29, 1-18 (1967).

[2] A. J. Shatkin, J. D. Sipe, and P. J. Loh, J. Virol. 2, 986 (1968).

[3] A. R. Bellamy and W. K. Joklik. J. Mol. Biol. 29, 19-26 (1967).

[4] J. Borsa and A. F. Graham, Biochem. Biophys. Res. Commun. 33, 895-901 (1968).

[5] R. L. Ward and A. J. Shatkin, Arch. Biochem. Biophys. 152, 378-384 (1972).

[6] H. Huismans and W. K. Joklik, Virology 70, 411-424 (1976).

[7] J. K. Christman, B. Reiss, D. Kyner, D. H. Levin, H. Klett, and G. Acs, Biochim. Biophys. Acta 294, 153-164 (1973).

[8] P. J. Gomatos and I. Tamm, Virology 17, 455-461 (1962).

[9] K. Köhler, Z. Naturforsch. 17 b, 544-547 (1962).

[10] S. J. Rhim and J. L. Melnick. Virology 15, 80-81 (1961).

[11] J.-P. Liautard, B. Setyono, E. Spindler, and K. Köhler, Biochim. Biophys. Acta 425, 373-383 (1976).

[12] S. Penman, J. Mol. Biol. 17, 117-130 (1966).

[13] C. W. Dingman and A. C. Peacock, Biochemistry 7, 659-668 (1968).

[14] A. C. Peacock and C. W. Dingman, Biochemistry 7, 668-674 (1968).

[15] U. K. Laemmli, Nature 227, 680-685 (1970). synthesis. If they have in addition a function in the morphogenesis of the virions remains to be elucidated.

\section{Acknowledgements}

The author wishes to thank Prof. Dr. K. Köhler, who initiated this work, for his interest and support. $\mathrm{He}$ is grateful to him and to Dr. J.-P. Liautard for many discussions, to Drs. D. Hülser and H.-D. Royer for help with the electron microscope and to U. Tayebi and D. Tromm for their valuable technical assistance. This work was supported by a grant (to K. K.) from the Deutsche Forschungsgemeinschaft.

[16] K. Weber and J. Osborn, J. Biol. Chem. 244, 44064412 (1969).

[17] G. Schochetman and R. P. Perry, J. Mol. Biol. 63, $577-586$ (1972).

[18] A. J. Shatkin, Biochem. Biophys. Res. Commun. 19, $506-510(1965)$.

[19] D. Baltimore and A. S. Huang, Science 162, 572-574 (1968).

[20] A. S. Spirin, Europ. J. Biochem. 10, 20-35 (1969).

[21] C. M. Stoltzfus, A. J. Shatkin, and A. K. Banerjee, J. Biol. Chem. 248, 7993-7998 (1973).

[22] J. R. Warner, P. Knopf, and A. Rich, Proc. Nat. Acad. Sci. USA 49, 122-129 (1963).

[23] S. Auerbach and T. Pederson, Biochem. Biophys. Res. Commun. 63, 149-153 (1975).

[24] R. L. Ward, A. K. Banerjee, A. La Fiandra, and A. J. Shatkin, J. Virol. 9, 61-69 (1972).

[25] U. Lindberg and B. Sundquist, J. Mol. Biol. 86, 451 468 (1974).

[26] G. Blobel, Proc. Nat. Acad. Sci. USA 70, 924-928 (1973).

[27] J.-P. Liautard and Ph. Jeanteur, Nucl. Acids Res. 7, $135-150$ (1979).

[28] H. Delius, H. Westphal, and N. Axelrod, J. Mol. Biol. 74, 677-687 (1973).

[29] J. Dubochet, C. Morel, B. Lebleu, and M. Herzberg, Europ. J. Biochem. 36, 465-472 (1973). 